\title{
Candida spp. occurrence in oral cavities of breastfeeding infants and in their mothers' mouths and breasts
}

\section{Presença de Candida spp. em boca de lactentes em aleitamento materno e em bocas e mamas de suas nutrizes}

\author{
Maria Stella Amorim da Costa Zöllner* \\ Antonio Olavo Cardoso Jorge**
}

\begin{abstract}
This study aimed to determine the occurrence of Candida spp. in the oral cavity of predominantly breastfed infants and in their mothers' mouths and breasts, as well as in the oral cavity of bottlefed infants and in non-lactating women. One hundred and sixty nine women and eighty-five milk-fed infants took part in this study and were divided into four groups: 1) infants predominantly on breastfeeding $(\mathrm{n}=55)$ and their mothers $(\mathrm{n}=55)$; 2$)$ infants on bottlefeeding $(\mathrm{n}=30)$; 3) non-lactating women on whom oral collections were performed $(\mathrm{n}=80)$ and, 4) non-lactating women on whom breast collections were performed $(n=34)$. Oral and mammary swabs were cultured on Sabouraud agar dextrose with chloramphenicol. The Candidayeast strains found were isolated and identified through morphological and biochemical tests. Candida species were much less frequent in infants who were predominantly breastfed than in those who were bottlefed. Yeasts were much more frequent on the breasts of lactating women, with statistical difference in relation to the control group.

DESCRIPTORS: Candida; Candida albicans; Candidiasis; Candidiasis, oral; Breast diseases; Breast feeding.
\end{abstract}

RESUMO: O objetivo do estudo foi verificar a presença de leveduras do gênero Candida na cavidade bucal de lactentes em aleitamento materno predominante e nas bocas e mamas de suas mães, assim como na cavidade bucal de lactentes em aleitamento artificial e em mulheres na ausência de lactação. Participaram do estudo 169 mulheres e 85 lactentes divididos em quatro grupos: 1) crianças em aleitamento natural predominante $(n=55)$ e suas mães $(n=55) ; 2)$ crianças em aleitamento artificial $(n=30)$; 3) mulheres que não estavam amamentando, em que se realizaram coletas bucais $(n=80)$ e, 4) mulheres em ausência de lactação em que se realizaram coletas mamárias ( $n=34)$. "Swabs" bucais e mamários, foram semeados em ágar Sabouraud dextrose com cloranfenicol, e as cepas de levedura isoladas foram identificadas utilizando-se provas morfológicas e bioquímicas. Espécies de Candida foram detectadas a partir de um número significativamente menor de crianças em aleitamento natural predominante que de crianças em aleitamento artificial. Também foi significativa a maior freqüência dessas espécies nas mamas de nutrizes em relação ao controle. DESCRITORES: Candida, Candida albicans; Candidíase; Candidiase bucal; Doenças mamárias; Aleitamento materno.

\section{INTRODUCTION}

Human milk is the ideal nourishment for neonates providing them with the necessary elements for their proper growth and development ${ }^{2,23}$.

The biological advantages found in the mother's milk are remarkable: it is a specific specimen, it has the ideal proportion of necessary proteins and high digestibility; it provides both nutrients in high bioavailability and also elements that aid the child's neural development, preventing atherosclerosis through the induction of the cholesterol biochemical means ${ }^{19,26}$. Besides other benefits, human milk helps prevent infections in neonates by developing resistance factors (phagocytic cells, IgA, complement) and by stimulating the infant's immunological system ${ }^{12,19,25,26,27,28}$. Breastfeeding also represents a complex whole of stimulating actions in the stomatognatic system development, leading to perfect oral functions and to the prevalence of nasal breathing ${ }^{25}$.

For breastfeeding to be effective, it ought to start as soon as possible, right in the delivery room, enabling its causing and supporting reflexes to take place peacefully and repeatedly ${ }^{2,25}$. However, when the lactating mother acquires breast candidiasis, which besides lesions on the areolae and nipples may also be accompanied by a sudden and intense pain while nursing ${ }^{1,9,13,14,15,18,23}$, she may shorten the breastfeeding time ${ }^{23}$ or choose to wean her baby, which is something still very common in our country ${ }^{2,10,26}$. Besides, oral candidiasis in breastfed infants may also become an obstacle to the whole breastfeeding process ${ }^{1,13,14,15,18,23}$. The rela-

\footnotetext{
*Assistant Professor, General Pathology; ${ }^{* *}$ Chairman, Microbiology and Immunology - University of Taubaté.
} 
Zöllner MSA da C, Jorge AOC. Candida spp. occurrence in oral cavities of breastfeeding infants and in their mothers' mouths and breasts. Pesqui Odontol Bras 2003;17(2):151-5.

tion between early weaning, malnutrition and infant mortality is notorious in poor countries.

Full comprehension of the process involved in Candida spp. colonization and its subsequent infection in breastfed infants and lactating women still requires a lot of investigation. Breast candidiasis is not duly taken into account and, at times, totally overlooked by physicians who should better advise breastfeeding mothers.

Nowadays, several species of Candida are considered to be of medical importance, such as: $C$. albicans, C. tropicalis, C. glabrata, C. parapsilosis, C. guilliermondii, C. krusei, C. kefyr and C. dubliniensis ${ }^{20,24}$. Such yeasts may occur like commensals in several niches of the human body and are usually transmitted from person-to-person ${ }^{6}$.

Both the oral presence of Candida spp. and oral candidiasis may be responsible for a systemic fungal infection in a debilitated individual ${ }^{7}$, which may lead to disastrous consequences.

Taking into account both the clinical and epidemiological aspects of Candida spp. colonization and oral candidiasis in breastfed infants, the present study investigated the prevalence of Candida spp. on lactating mothers' breasts and in their breastfed infants' oral cavity.

\section{METHODS}

This study comprised 169 women and 85 breastfed infants, divided into four groups: 1) 55 lactating mothers (who had their breasts and mouths swabbed) and their babies, who were being predominantly breastfed (mother's milk as a predominant nourishing source/World Health Organization indicator), and who had samples collected from their mouths. These people were recruited at basic health units in the city of Taubaté, state of São Paulo, Brazil. Most of them belonged to the lower middle class, and a small part of the group lived in near misery conditions. This study included infants and mothers who came to health units for regular pediatric appointments or for vaccination, and who conformed with the study age group and with the feeding condition. Both mothers' and infants' general health and nutrition levels were assessed, as well as the breastfed infants' gestational period and birth, in order to determine the profile of the study individuals; 2) 30 infants on artificial feeding, in the same age group as those on breastfeeding (up to five months of age, for oral sample collections); 3) 80 non-pregnant and non-lactating women who came to the dental clinic, University of Taubaté (UNITAU), for a pro- grammed dental treatment, in whose mouths Candida was found; 4) 34 non-pregnant and non-lactating women who attended the public health service for gynecological examinations, on whose breasts Candida spp. were found. Samples were collected in neighborhoods that had a significant geographical distribution in our city. All groups included people who had a similar socioeconomic profile.

Adult patients were given proper advice, in a clear and informative language, by the researchers, and then signed a form for themselves and their children agreeing to participate in this study. Not a single one refused to do so. The study was approved by the Ethical Research Committee, School of Dentistry of São José dos Campos, São Paulo State University.

Samples were collected with tongue swabs from the infants and from their mothers, and with premoistened swabs from the skin of the women's nipples and areolae. The samples were then inoculated on Sabouraud dextrose agar plates (Difco, Detroit, USA) with chloramphenicol (Carlo Erba, Rio de Janeiro, Brasil; $0.1 \mathrm{mg} / \mathrm{ml}$ ) and immediately taken to the Microbiology Laboratory, University of Taubaté. The plates were kept at $37^{\circ} \mathrm{C}$ for 48 hours and then at room temperature for another five days. After yeast colonies had grown, scraping was performed using the Gram-stained method, for microscopic assessment of the constituent cells and for the necessity of purifying the cultures before final identification. Such identification was performed by considering the germ tube production in sterile rabbit serum, chlamydospores, hyphae and yeasts in the microculture in cornmeal Tween 80 (Difco, Detroit, USA) agar, carbohydrate assimilation and fermentation $^{22}$.

The results obtained from the study of the prevalence of Candida spp. in the examined individuals were statistically analyzed according to the significance test for the similarity of two proportions ( $p<0.05)$. The proportions of yeast occurrence were tested in two groups of individuals, which were compared concerning the presence or absence of breastfeeding. The groups were paired in the following way: infants who were fed by the two studied feeding patterns; mouths of women who were breastfeeding or not, and breasts of women in the same conditions. Odds ratio was calculated for these groups. 
Zöllner MSA da C, Jorge AOC. Candida spp. occurrence in oral cavities of breastfeeding infants and in their mothers' mouths and breasts. Pesqui Odontol Bras 2003;17(2):151-5.

\section{RESULTS}

All the samples collected for this study, as well as the description of the subpopulation analyzed, are shown on Table 1.

Candida spp. were found in at least one of the two body niches analyzed in 38 out of 55 mother-breastfed infant pairs (Table 2), where 77 isolates were found. In 17 pairs, there was simultaneous occurrence of Candida spp. in both individuals. In the remaining ones, yeast was present only in the mothers' mouths in 13 cases, only on the mothers' breasts in six cases and only in the breastfed infants' mouths in two cases.

Thirty oral samples were collected and 26 isolates were obtained from infants who were up to five months old on artificial feeding. For the group

TABLE 1 - Groups of individuals who were studied as to the presence of Candida genus yeasts in their oral cavities and on their breasts.

\begin{tabular}{|c|c|c|c|c|}
\hline Groups & $\mathrm{n}$ & $\begin{array}{l}\text { Age } \\
\text { group }\end{array}$ & $\begin{array}{c}\text { Collections } \\
\text { from }\end{array}$ & $\begin{array}{l}\text { Number of } \\
\text { sample } \\
\text { collections }\end{array}$ \\
\hline $\begin{array}{l}\text { Infants on } \\
\text { breastfeeding }\end{array}$ & 55 & $\begin{array}{c}1-5 \\
\text { months }\end{array}$ & Mouth & 55 \\
\hline \multirow[t]{2}{*}{ Lactating women } & \multirow{2}{*}{55} & \multirow{2}{*}{$\begin{array}{l}17-40 \\
\text { years }\end{array}$} & Mouth & 55 \\
\hline & & & Breasts & 110 \\
\hline $\begin{array}{l}\text { Infants on artificial } \\
\text { feeding }\end{array}$ & 30 & $\begin{array}{l}1-5 \\
\text { months }\end{array}$ & Mouth & 30 \\
\hline \multirow[t]{2}{*}{$\begin{array}{l}\text { Non-lactating } \\
\text { women }\end{array}$} & 80 & $\begin{array}{l}21-35 \\
\text { years }\end{array}$ & Mouth & 80 \\
\hline & 34 & $\begin{array}{l}17-40 \\
\text { years }\end{array}$ & Breasts & 68 \\
\hline Total & 254 & & & 398 \\
\hline
\end{tabular}

TABLE 2 - Prevalence of Candida spp. in infants and women in the presence and absence of breastfeeding.

\begin{tabular}{l|c|c|c|c|c|c}
\hline \hline \multirow{2}{*}{$\begin{array}{c}\text { Examined } \\
\text { places }\end{array}$} & \multicolumn{3}{|c|}{ Breastfeeding } & \multicolumn{3}{c}{ Non-breastfeeding } \\
\cline { 2 - 7 } & $\mathrm{n}$ & $\begin{array}{c}\% \\
\text { positives }\end{array}$ & $\mathrm{n}$ & $\begin{array}{c}\mathrm{n} \\
\text { positives }\end{array}$ & $\begin{array}{c}\% \\
\text { positives } \\
\text { positives }\end{array}$ \\
\hline $\begin{array}{l}\text { Infant's } \\
\text { mouth }\end{array}$ & 55 & 19 & $34.55^{*}$ & 30 & 20 & 66.67 \\
\hline $\begin{array}{l}\text { Women's } \\
\text { mouth }\end{array}$ & 55 & 24 & 43.63 & 80 & 35 & 43.75 \\
\hline $\begin{array}{l}\text { Women's } \\
\text { breast }\end{array}$ & 55 & 19 & $34.55^{*}$ & 34 & 6 & 17.65 \\
\hline \hline
\end{tabular}

*Statistically significant difference (p < 0.05). of 80 women, in a similar age group to that of the breastfeeding women from whom oral samples were collected, 35 isolates were obtained. In the group of 34 women in the same age group as those in the study group from whom 68 mammary samples were collected (from each individual, one sample was collected from the left breast and one from the right breast), ten strains were isolated (Table 2).

The prevalence of several candidal species found in both breastfed and bottlefed infants are shown on Table 3.

The prevalence of Candida spp. found in the study women in the breastfeeding and non-breastfeeding groups is shown on Table 4.

TABLE 3 - Percentage of Candida species found in the mouths of infants on breastfeeding and on artificial feeding.

\begin{tabular}{l|rr|rc}
\hline \multicolumn{1}{c|}{ Species } & \multicolumn{2}{|c|}{ Breastfeeding } & \multicolumn{2}{c}{ Artificial feeding } \\
\hline C. albicans & 11 & $(57.89 \%)$ & 12 & $(46.15 \%)$ \\
\hline C. parapsilosis & 5 & $(26.32 \%)$ & 6 & $(23.08 \%)$ \\
\hline C. tropicalis & 2 & $(10.53 \%)$ & 5 & $(19.23 \%)$ \\
\hline C. guilliermondii & 1 & $(5.26 \%)$ & 2 & $(7.69 \%)$ \\
\hline C. krusei & \multicolumn{2}{|c|}{-} & 1 & $(3.85 \%)$ \\
\hline Total of strains & $19(100 \%)$ & $26(100 \%)$ \\
\hline \hline
\end{tabular}

TABLE 4 - Percentage of Candida spp. found in women's mouths and breasts.

\begin{tabular}{l|c|c|c|c}
\hline \hline \multirow{2}{*}{ Species } & \multicolumn{2}{|c|}{ Breastfeeding } & \multicolumn{2}{c}{ Non-breastfeeding } \\
\cline { 2 - 5 } & $\%$ mouth & $\%$ breast & $\%$ mouth & $\%$ breast \\
\hline C. albicans & $69.23^{*}$ & 34.61 & 91.43 & 20 \\
\hline C. glabrata & $11.54 *$ & - & - & - \\
\hline C. parapsilosis & 7.69 & 15.38 & 2.86 & - \\
\hline C. lipolytica & 3.85 & - & - & - \\
\hline C. tropicalis & - & $38.46^{*}$ & 5.71 & 10 \\
\hline C. krusei & 3.85 & 3.85 & - & - \\
\hline C. famata & 3.85 & $3.85^{*}$ & - & 40 \\
\hline C. guilliermondii & - & $3.85^{*}$ & - & - \\
\hline C. kefyr & - & - & - & $20 *$ \\
\hline C. lusitaniae & - & 3.85 & - & 10 \\
\hline Total of strains & 26 & 26 & 35 & 10 \\
\hline \hline
\end{tabular}

*Statistically significant difference ( $<$ 0.05). 
Zöllner MSA da C, Jorge AOC. Candida spp. occurrence in oral cavities of breastfeeding infants and in their mothers' mouths and breasts. Pesqui Odontol Bras 2003;17(2):151-5.

\section{DISCUSSION}

The sample of 55 mother-children pairs comprised in this study was taken into account based on the data of the SINASC (System of Information on Children Born Alive, Health Ministry, Brazil) for the mean number of 1,565 infants expected to live up to the age of five months for a certain month in the year 2000 in our city, and also on the data from the files of Taubaté's Municipal Epidemiological Surveillance for the expected percentage of breastfed infants (25\% or 375 individuals). Considering its geographical distribution, the samples comprise such community.

A prevalence of $34.55 \%$ for Candida spp. was found in the mouths of predominantly breastfed infants (who did not use either pacifiers or any other kind of rubber nipples) and $66.67 \%$ in the ones who were strictly bottlefed. Such differences were statistically significant. Hoppe ${ }^{8}$ considered both feeding bottles and pacifiers as transmission means, important factors in the artificially fed infant group. The frequent presence of a feeding bottle nipple, usually containing hot nourishments and with extremely different hygienic levels ${ }^{8}$, works as an irritability factor to the mucosa and leads to changes in the local microbiota ${ }^{16}$. Breast milk contains resistance factors, like lysozyme and lactoferrin ${ }^{19}$, which can protect breastfed infants against Candida colonization in their oral cavity. By studying artificial feeding as a risk factor for the presence of oral Candida, an odds ratio equal to 3.77 was obtained (which shows that the study case is more likely to happen in the bottlefed group).

A similar occurrence was observed in the distribution of Candida species among infants, regardless of feeding patterns, although with different percentages. In both groups, there was a prevalence of C. albicans, a member of the normal microbiota on the mucosae of respiratory, gastrointestinal and genital tracts and on the skin. Thus, the species is highly transmitted from the adult population to infants ${ }^{5,721}$. Yeast adherence to the oral mucosa is a relevant first step for the colonization and it contributes to its persistence in the area. The germ tube (characteristic of $C$. albicans) renders such adherence favorable ${ }^{4,11,17}$, making this peculiarity a plausible explanation for the larger prevalence of this species in both individual groups.

In both study groups, the second commonest yeast was C. parapsilosis, a species usually pres- ent in human hands ${ }^{11,28}$, which might explain its prevalence in the two groups.

Concerning the oral presence of Candida genus in women, a quite similar prevalence was found in both breastfeeding and non-breastfeeding groups. That may be explained due to the fact that the study groups equally comprised young and healthy women. When these groups were compared regarding breastfeeding, odds ratio calculation equals to 1 , which virtually presents the same chances of yeast occurrences in both of them.

Concerning the presence of Candida spp. on women's breasts, some authors refer, in a general aspect, that it would only occur during the breastfeeding process ${ }^{1,13,18,23}$. In the present study, Candi$d a$ was found on the breasts of both lactating women (34.55\%) and non-lactating women (17.65\%), but the difference was statistically significant. There is a clearly larger presence of this yeast on lactating women's breasts, whose moistened surface, macerated and exposed to constant traumas, would create perfect conditions for such event to take place ${ }^{13,14,23}$, due to the probable exposition of new tissue receptors to yeast adherence. Considering breastfeeding as a risk factor for the presence of Candida spp. on the study women's breasts, odds ratio equals to 2.52, which confirms this observation. Among the samples isolated in these niches, statistically significant differences for C. tropicalis and C. guilliermondii were found, whereas C. kefyr occurred only in the second group. Such results lead to the possibility that different hormonal conditions and the presence of mother's milk have rendered the feeding breast more favorable to Candida rare species colonization.

In 17 mother-breastfed infant pairs, there was simultaneous occurrence of Candida genus species in both elements: mother and infant. In the absolute majority of such pairs, there was a coincidence of species $(81.81 \%$ of the cases) in the infants' mouths and on their mothers' breasts. This fact establishes a clear communication means between those two niches in those two individuals.

There was a prevalence of Candida spp. in $34.55 \%$ of breastfed infants' mouths and in $66.67 \%$ of those who were bottlefed (statistically significant difference), which suggests that breastfeeding should be a protective factor against infant's oral colonization by Candida genus yeasts.

It has been observed that although there is a significantly larger quantity and larger diversity of 
candidal species on the breasts of the study lactating women, the fact that an expressively smaller number of breastfed infants had their mouths colonized by this type of yeast confirms the idea of protection provided by resistance factors in mother's milk against the Candida genus colonization in the oral cavities of breastfed infants.

The importance of considering this additional protection of breastfeeding for the infants' health

\section{REFERENCES}

1. Amir LH, Pakula S. Nipple pain, mastalgia and candidiasis in the lactating breast. Aust N Z J Obstet Gynaecol 1991;31:378-80.

2. Arantes CIS. Amamentação: visão das mulheres que amamentam. J Pediatr 1995;71:195-202.

3. Baley JE. Neonatal candidiasis: the current challenge. $\mathrm{Cl}$ Perionatol 1991;18:263-81.

4. Cannon RD, Holmes AR, Mason AB, Monk BC. Oral Candida: clearence, colonization or candidiasis. J Dent Res 1995;74:1152-61.

5. Darwazeh AMG, Al Bashir A. Oral candidal flora in healthy infants. J Oral Pathol Med 1995;24:361-4.

6. Edman JC. Micologia médica. In: Brooks GF, Ornston LN, Jawetz E, Melnick JL, Adelberg EA. Microbiologia médica. $20^{\text {th }}$ ed. Rio de Janeiro: Guanabara-Koogan; 1998. p.420-43.

7. Gupta P, Faridi MMA, Rawat S, Sharma LP. Clinical profile and risk factors for oral candidosis in sick newborns. Indian Pediatr 1996;33:299-303.

8. Hoppe JE. Treatment of oropharyngeal candidiasis in immunocompetent infants: a randomized multicenter study of miconazol gel $v$ s. nystatin suspension. Pediatr Infect Dis J 1997;16:288-93.

9. Jain E. Yeast infections and breastfeeding. Can Nurse 1996;92:5-6.

10. Kummer SC, Giugliani ERJ, Susin LO, Folletto JC, Lermen NR, Wu VYJ. Evolução do padrão de aleitamento materno. Rev Saúde Publica 2000;34:143-8.

11. Lacaz CS, Porto E, Heins-Vaccari EM, Melo NT. Leveduras de interesse médico. In: Guia para identificação: fungos actinomicetos, algas de interesse médico. $1^{\text {st }}$ ed. São Paulo: Sarvier; 1998, p.86-120.

12. Machado CSM. Desenvolvimento da resposta imune de mucosas: influências do aleitamento materno e ambientais. $\mathrm{J}$ Pediatr 1995;71:241-7.

13. Mac Donald H. Candida: the hidden deterrent to breastfeeding. Can Nurse 1995;91:27-30.

14. Mukherjee SC. Moniliasis breast. J Ind Med Assoc 1964;43:536-8. is that, besides restraining the occurrence of oral candidiasis in an individual who still has not achieved all his immunological potentials, it will also prevent the entry of such yeasts in deeper locations of the human body. It is important to remind, however, that in debilitated or immunocompromised individuals, Candida spp. causes serious infections, which are very difficult to be trea ted $^{3,11}$.

15. Nanjappa-Chetty G, Selvi GS, Kamalam A, Thambiah AS. Candidosis in mother and child. Mycosen 1979;23:580-2.

16. Neville BW, Damm DD, Allen CM, Bouquot JE. Fungal and protozoal diseases: candidiasis. In: Oral and maxillofacial pathology. $1^{\text {st }}$ ed. Philadelphia: Saunders; 1995. p.163-9.

17. Olsen I. Oral adhesion of yeasts. Acta Odontol Scand 1990;48:45-53.

18. Pakula S. Thrush during lactation. Aust Fam Physician 1998;27:672.

19. Penna HAO, Lima IN, Bresolin AMB, Issler H, Slywitch MV, Schvartsman S. Higiene alimentar. In: Marcondes E. Pediatria básica. $8^{\text {th }}$ ed. São Paulo: Sarvier; 1999. p.79-108.

20. Perduca M, Marangoni E, Guanziroli A, Romero E, Filice G. Fungaemia in hospitalized patients. Mycoses 1995: 38(9/10):385-7.

21. Rindum JL, Stenderup A, Holmstrup P. Identification of Candida albicans types related to healthy and pathological oral mucosa. J Oral Pathol Med 1994;23:406-12.

22. Sandvén P. Laboratory identification and sensitivity testing of yeast isolates. Acta Odontol Scand 1990;48:27-36.

23. Saunders S. Breast pain in the lactating mother. Midwives 1997;110(1308):8-9.

24. Shepherd MG. Biology of Candida species. In: Samaranayake LP, Mac Farlane TW. Oral candidosis. $1^{\text {st }}$ ed. London: Wrigth; 1990. p.10-20.

25. Tollara MN, Corrêa MSNP, Bönecker MJS, Carvalho GD. Aleitamento natural. In: Correa MSNP. Odontopediatria na primeira infância. $1^{\text {st }}$ ed. São Paulo: Santos; 1998. p.71-86.

26. Victora CG, Barros AJD, Fuchi SC, De Francisco A, Morris J, May AJ. Effect of breastfeeding on infant and child mortality due to infectious diseases in less developed countries: a pooled analysis. Lancet 2000;355:451-5.

27. Vieira GO, Glisser M, Araújo SPT, Sales AN. Indicadores de aleitamento materno na cidade de Feira de Santana, Bahia. J Pediatr 1998;74:11-6.

28. Weems Jr JJ. Candida parapsilosis: epidemiology, pathogenicity, clinical manifestations and antimicrobial susceptibility. Clin Infect Dis 1992;14:756-66.

Recebido para publicação em 25/06/02 Enviado para reformulação em 14/03/03 Aceito para publicação em 14/04/03 